\title{
Crystallized Phenol Treatment in Postoperative Recurrent Pilonidal Disease
}

\author{
Zülfü Bayhan, Sezgin Zeren, Şükrü Aydın Düzgün
}

\begin{abstract}
Objective: A variety of surgical and minimally invasive treatment options are available to treat pilonidal sinus disease. Recurrence after surgery is a major problem. In addition to the surgical treatment of post-surgical recurrences, minimally invasive treatment methods are also available. In our study, we aimed to investigate the results of crystallized phenol application on patients who were admitted to our clinic with post-surgical pilonidal sinus recurrence.
\end{abstract}

Methods: The data of 26 patients who were admitted to our clinic with postoperative pilonidal sinus recurrence and who were treated by crystallized phenol treatment were analyzed. Patients were evaluated in terms of age, gender, previous surgery, crystallized phenol application count, follow -up period and wound infection.

Results: Data of 26 patients were analyzed.3 patients (11.5\%) were admitted with recurrence after Modified Limberg surgery. 11 patients (42.3\%) were admitted with recurrence after Limberg flap surgery and12 patients (46.15\%) were admitted with recurrence after primary repair. 19 patients (73.02\%) were treated by one time crystallized phenol application. 5 (19.23\%) patients underwent a second time application and provided treatment after the second application. The cure was achieved in 24 (92.3\%) patients after repeated applications.

Conclusion: Crystallized phenol application is a minimally invasive treatment method that can be applied easily under local anesthesia. The method has a high success rate after repeated applications in patients with recurrence after surgery and is a very good alternative to surgical therapy. J Clin Exp Invest 2016; 7 (1): 19-22

Key words: Recurrent pilonidal disease, crystallized phenol treatment, minimally invasive treatment

\section{Cerrahi Sonrası Nüks Pilonidal Sinüs Hastalığında Kristalize Fenol Tedavisi}

\section{ÖZET}

Amaç: Pilonidal sinüs tedavisinde çeşitli cerrahi ve minimal invaziv tedavi seçenekleri mevcuttur. Cerrahi sonrasında nüks önemli bir problemdir. Cerrahi sonrası nüksün tedavisinde de cerrahi tedavilere ek olarak minimal invaziv yöntemler kullanılabilir. Çalışmamızda pilonidal sinüs cerrahisi sonrasında rekürrens ile kliniğimize başvuran hastalarda yapılan kristalize fenol uygulamasının sonuçlarını retrospektif olarak incelemeyi amaçladık.

Yöntemler: 2013 Ekim ile 2016 Ocak tarihleri arasında Dumlupınar Üniversitesi Tıp fakültesi- Evliya Çelebi eğitim ve araştırma hastanesinde cerrahi operasyon sonrası gelişen nüks Pilonidal sinüs hastalığı nedeniyle Kristalize fenol uygulaması tedavisi yapılan toplam 26 hastanın verileri retrospektif olarak incelendi. Tedavi edilen hastalar yaş, cinsiyet, geçirdiği cerrahi operasyon, Kristalize fenol uygulama sayısı, yara yeri enfeksiyonu ve takip süresi açısından değerlendirildi.

Bulgular: Cerrahi sonrası nüks gelişen ve kristalize fenol uygulaması yapılan 26 hastanın verileri incelendi. 3 hasta $(\% 11,5)$ Modifiye Limberg operasyonu sonrasında nüks ile başvurdu. 11 hasta Limberg Flep operasyonu $(\% 42,3)$ ve 12 hastada primer onarım $(\% 46,15)$ sonrasında nüks ile başvurdu. 19 hasta $(\% 73,02) 1 \mathrm{kez}$ kristalize fenol uygulaması sonrasında tedavi edildi. $5(\% 19,23)$ hastaya 2. Kez uygulama yapıldı ve 2. Uygulama sonrasında tedavi sağlandı. Tekrarlayan seanslar sonrasında $24(\% 92,3)$ hastada kür sağlandı.

Sonuç: Kristalize fenol uygulaması lokal anestezi altında kolaylıkla uygulanabilen minimal invaziv bir yöntemdir. Cerrahi sonrası rekürrens görülen hastalarda tekrarlayan uygulamalar sonrasında yüksek başarı oranına sahiptir ve cerrahi tedaviye çok iyi bir alternatiftir.

Anahtar kelimeler: Nüks pilonidal sinüs, kristalize fenol tedavisi, minimal invaziv tedavi

Department of General Surgery, Faculty of Medicine, Dumlupinar University, Kutahya, Turkey

Correspondence: Zulfu Bayhan,

Assistant Professor of General Surgery, Department of General Surgery, Faculty of Medicine, Dumlupinar University, Kutahya 43100, Turkey Email: zulfubayhan@gmail.com

Received: 11.01.2016, Accepted: 10.02.2016

Copyright (C) JCEI / Journal of Clinical and Experimental Investigations 2016, All rights reserved 


\section{INTRODUCTION}

Many surgical and conservative treatment methods are defined for pilonidal sinus but the ideal treatment could not be determined [1,2]. The ideal treatment of pilonidal sinus disease should be with a minimum amount of tissue excision and the lowest recurrence [3]. However, factors such as minimum length of hospital stay, return to active life quickly, minimal loss of work force and cosmetic appearance are important therapeutic targets. Thus the pit excision, mechanical cleaning of sinus tracts and easily applicable treatment methods, such as chemical treatment has aroused great interest in the treatment of pilonidal sinus [4].

In recent years crystalized phenol treatment has been one of the most interesting minimally invasive methods in the treatment of pilonidal sinus disease. After surgery a variety of complications can be seen such as wound infection, seroma and wound dehiscence. These complications were observed less with minimally invasive techniques [5]. The recurrence of the disease after surgery is a much more important condition. The rates of recurrence after surgery show differences according to surgical methods which were applied. Recurrence rates range between $0-20 \%$ in different surgical procedures [6,7]. Crystallized phenol treatment can be applied as a minimally invasive treatment option to the patients who have recurrent disease after surgery. The aim of our study is to investigate the results of the crystallized phenol application in patients with recurrence after pilonidal sinus surgery as retrospectively.

\section{METHODS}

Data of 26 patients who were admitted to Dumlupinar University- Evliya Celebi Education and Research Hospital and achieved crystallized phenol application between October 2013 and January 2016 with recurrent pilonidal disease after surgery were analyzed retrospectively. Primary disease, patients who developed recurrence after first crystallized phenol application, patients with chronic diseases were excluded from the study. Patients aged between 18 to 60 without any chronic disease, patients with recurrent pilonidal disease after surgery were included to the study. The patients with abscess formation were treated with crystallized phenol following abscess drainage and antibiotherapy. Repeated applications were made to the patients who were not healed by one time application. Patients were evaluated retrospectively in terms of age, gender, previous surgery, number of crystallized phenol applications, wound infection and follow-up period. An informed consent was obtained from the patients for crystallized phenol application. Personal identity of the patients was not shared in this study.

\section{Crystallized phenol application procedure}

After the application of local anesthesia a millimetric circumferential incision was performed to excise the pits with a fine blade. Hair and debris were removed in the sinus tract with a curved clamp. The inside of the sinus tract is curetted. A pomade containing Nitrofurantoin was applied to the surrounding skin tissue just before the phenol application into the sinus tract. Than crystallized phenol particles were inserted to the tract with the help of a clamp until the tract is full. After dressing the procedure was finished and patient was discharged at once.

\section{Healing criteria for crystallized phenol application in recurrent pilonidal disease}

Complete closure of wound opening, interruption of wound discharge, the disappearance of the induration and the absence of pain were accepted as healing criteria after application.

\section{Statistical Analysis}

Data were analyzed by descriptive statistics, averages and standard deviations for continuous variables, percentage and numbers were used for categorical data.

\section{RESULTS}

Data of 26 patients who have recurrent pilonidal disease after surgery and applied crystallized phenol application were analyzed. Sociodemographic characteristics and results of patients treated with crystallized phenol application were presented in Table 1. Patients' ages ranged from 18 to 36 . There were $5(19.23 \%)$ female and $21(80.76 \%)$ male patients available. 3 patients $(11.5 \%)$ were admitted with recurrence after Modified Limberg surgery. 11 patients $(42.3 \%)$ were admitted with recurrence after Limberg flap surgery and 12 patients $(46.15 \%)$ were admitted with recurrence after primary repair (Figure 1). 19 patients $(73.02 \%)$ were treated by one time crystallized phenol application. $5(19.23 \%)$ patients underwent a second time application and provided treatment after the second application. 2 patients $(7.69 \%)$ had the application third time but complete healing has not been 
provided yet. The cure was achieved in 24 (92.3\%) patients after repeated applications. Repeated crystallized phenol treatment is still ongoing in two patients who did not have complete healing at the end of third application yet. Wound infection was developed in 4 patients $(15.38 \%)$. Follow-up period ranged from 3 months to 24 months after the application and the average follow-up period is determined as 12.1 months.

Table 1. Sociodemographic characteristics and results of patients treated with crystallized phenol application $(n=23)$

\begin{tabular}{lc}
\hline Age (Mean \pm SD) & $25 \pm 4.7$ \\
Follow-up period (Mean \pm SD) & $12.1 \pm 4.6$ \\
Gender, Female / Male & $5 / 21$ \\
Single / Multiple applications & $19 / 6$ \\
Wound infection & $4 / 22$ \\
\hline
\end{tabular}

SD: Standard deviation

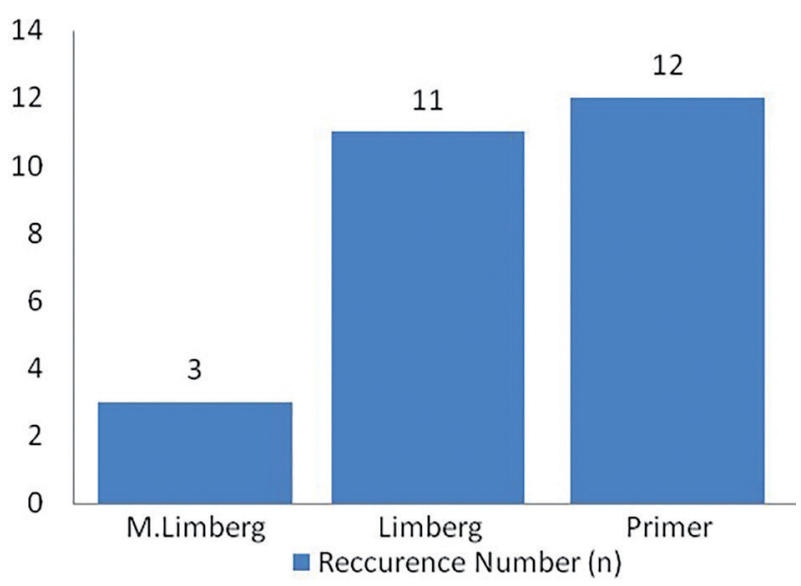

Figure 1. Distribution of patients admitted with postoperative recurrent pilonidal disease according to initial surgical procedure

\section{DISCUSSION}

There are many treatment options of pilonidal sinus disease. The vast majority of these methods are the surgical procedures. These surgical methods include excision and primary repair, secondary healing and flap repair procedures [8]. In addition to these minimally invasive methods such as phenol application is also applied increasingly in recent years in the treatment of pilonidal sinus [9]. Targeted treatment of pilonidal sinus surgery should be simple, painless, cost effective, does not require hospitalization, minimum time of away from work and minimum recurrence
[10]. From this point phenol application is a method that can reach all these goals.

The most important problems of pilonidal sinus treatment are complications, recurrence of disease and aesthetic results [11]. Surgical procedures are the main treatment options especially in recurrent disease. Operative procedures such as Limberg flap, Karydakis flap, fasiocutaneous V-Y advancement flap reconstruction and Cleft lift procedure are used in recurrent and complicated disease. High rates of success was obtained for the treatment of recurrent disease with these surgical procedures [12-15]. Besides this, several minimally invasive methods are also available such as laser hair removal and crystallized phenol application and these methods can be applied in postoperative recurrence of pilonidal disease $[10,16]$.

To the best of our knowledge, there are a few studies available on viewing the results of crystallized phenol application on postoperative recurrent pilonidal disease. In a study done by Aygen et al. it has been stated that after multiple applications of crystallized phenol application, a high rate $(91.7 \%)$ of success is achieved in postoperative recurrent pilonidal disease [17]. Findings of our study also support this work. In our study, complete healing was achieved in 19 patients $(71.87 \%)$ after a single application. Full recovery was achieved in 24 patients $(92.3 \%)$ after multiple applications. According to our results, we suggest that crystallized phenol application may be a good alternative to reoperation in treatment of postoperative recurrent pilonidal disease.

Single time crystallized phenol application may have relatively low success rate compared to surgical treatment. On the other hand, major advantages of this application are being minimally invasive procedure, can be repeated easily, does not require hospitalization and high complete remission rate after repeated applications.

In our study, wound infection was developed in 4 patients $(15.38 \%)$. Wound infections were treated by medical therapy and dressing applications. Wound infection rates were found similar in several studies after various flap procedures for postoperative recurrent pilonidal sinus treatment $[15,18]$.

As a result, crystallized phenol application is a method of treatment that can be easily performed under local anesthesia. The method has also a high success rate in postoperative recurrent pilonidal disease patients. The most important advantages of this meth- 
od are being easily repeatable, do not require hospitalization, having better cosmetic results. Crystallized phenol application is a very good alternative to surgical treatment and may be preferred in treatment of recurrent pilonidal disease after surgery.

Declaration of Conflicting Interests: The authors declare that they have no conflict of interest.

Financial Disclosure: No financial support was received.

\section{REFERENCES}

1. Kaya B, Uctum Y, Simsek A, Kutanis R. Treatment of pilonidal sinus with primary closure. A simple and effective method. Kolon Rektum Hast Derg 2010;20:59-56.

2. Chintapatla S, Safarani N, Kumar S, Haboubi N. Sacrococcygeal pilonidal sinus: historical review, pathological insight and surgical options. Tech Coloproctol 2003;7:3-8.

3.Sözen S, Topuz O, Dönder Y, et al. Comparison between Karydakis flap repair and Limberg flap for surgical treatment of sacrococcygeal pilonidal sinus (short term results). Ulusal Cer Derg 2010;26:153-156.

4. Isik A, Eryılmaz R, Okan I, et al. The use of fibrin glue without surgery in the treatment of pilonidal sinus disease. Int $\mathrm{J}$ Clin Exp Med 2014;7:1047-1051.

5. Akan K, Tihan D, Duman U, et al. Comparison of surgical Limberg flap technique and crystallized phenol application in the treatment of pilonidal sinus disease: a retrospective study. Ulus Cerrahi Derg 2013;29:162-166.

6. Caglayan K, Gungor B, Topgul K, et al. Investigation of patient dependent factors effecting complications and recurrence in pilonidal sinus disease. Kolon Rektum Hast Derg 2011;21:103-108.

7. Ertan T, Koc M, Gocmen E, et al. Does technique alter quality of life after pilonidal sinus surgery? Am J Sur 2005; 190:388-392.
8. Aydede H, Erhan Y, Sakarya A, Kumkumoglu Y. Comparison of three methods in surgical treatment of pilonidal disease. ANZ J Surg 2001;71:362-364.

9. Dogru O, Camci C, Aygen E, et al. Pilonidal sinus treated with crystallized phenol: an 8 year experience. Dis Colon Rectum 2004;47:1934-1938.

10. Girgin M, Kanat BH, Ayten R, et al. Minimally invasive treatment of pilonidal disease: crystallized phenol and laser depilation.Int Surg 2012;97:288-292.

11. Muzi MG, Milito G, Cadeddu F, et al. Randomized comparison of Limberg flap versus modified primary closure for the treatment of pilonidal disease. Am J Surg 2010;200:9-14.

12. Schoeller T, Wechselberger G, Otto A, Papp C. Definite surgical treatment of complicated recurrent pilonidal disease with a modified fasciocutaneous V-Y advancement flap. Surgery 1997;121:258-63.

13. Eryilmaz R, Okan I, Coskun A, et al. Surgical treatment of complicated pilonidal sinus with a fasciocutaneous V-Y advancement flap. Dis Colon Rectum 2009;52:2036-2040.

14. Rushfeldt C, Bernstein A, Norderval S, Revhaug A. Introducing an asymmetric cleft lift technique as a uniform procedure for pilonidal sinus surgery. Scand J Surg 2008;97:77-81.

15. Bali I, Aziret M, Sozen S, et al. Effectiveness of Limberg and Karydakis flap in recurrent pilonidal sinus disease. Clinics (Sao Paulo) 2015;70:350-355.

16. Downs AM, Palmer J. Laser hair removal for recurrent pilonidal sinus disease. J Cosmet Laser Ther 2002;4:91.

17. Aygen E, Arslan K, Dogru O, et al. Crystallized phenol in nonoperative treatment of previously operated, recurrent pilonidal disease. Dis Colon Rectum 2010;53:932-935.

18. El-Khadrawy O, Hashish M, Ismail K, Shalaby H. Outcome of the rhomboid flap for recurrent pilonidal disease. World J Surg 2009;33:1064-1068. 